\title{
PERENCANAAN UMUM PENANAMAN MODAL (RUPM) KOTA TANGERANG SELATAN
}

\author{
Abdul Hamid \\ UIN Syarif Hidayatullah Jakarta \\ abdul.hamid@uinjkt.ac.id
}

\begin{abstract}
.
This study aims to formulate and plan for capital investment policy and also to formulating investment improvement strategy in South Tangerang City. The method used Analitycal Hierarchy Process (AHP) and SWOT analysis. From the result indicate the direction of policy stakeholders' opinion: (1) Improvement of Investment Climate, (2) Encouraging Investment Distribution, (3) Focus on Food Development, Infrastructure and Energy, (4) Empowerment of Micro, Small, Medium, and Cooperative (MSME), (5) Provision of Facilities, Convenience, and / or the Investment Incentives, and (6) Investment Promotion. The prioritized sectors are trade, industry, hotel and restauran as first priority sector with eigenvalues vector of 0.232 , the second priority is health sector with eigenvalues vector of .202, the third priority of education with the third largest eigen vector 0.199 , the fourth priority sectors is agriculture, livestock and fisheries with eigenvalues vector of 0.192 and the last priority is tourism sector with eigenvalues vector only of 0.169 .
\end{abstract}

Keywords: AHP; SWOT; RUPM; UMKMK; Investment Policy

\begin{abstract}
Abstrak.
Penelitian ini bertujuan untuk merumuskan dan merencanakan kebijakan penanaman modal dan juga untuk merumuskan strategi peningkatan investasi di Kota Tangerang Selatan. Metode yang digunakan Analitycal Hierarchy Process (AHP) dan analisis SWOT. Dari hasil penelitian menunjukkan arah pendapat para pemangku kepentingan kebijakan: (1) Peningkatan Iklim Investasi, (2) Mendorong Distribusi Investasi, (3) Fokus pada Pengembangan Pangan, Infrastruktur dan Energi, (4) Pemberdayaan Usaha Mikro, Kecil, Menengah, dan Koperasi (UMKM), (5) Penyediaan Fasilitas, Kenyamanan, dan / atau Insentif Investasi, dan (6) Promosi Investasi. Sektor prioritas adalah perdagangan, industri, hotel dan restauran sebagai sektor prioritas pertama dengan nilai eigen vektor dari 0,232, prioritas kedua adalah sektor kesehatan dengan nilai eigen vektor dari 0,202, prioritas ketiga pendidikan dengan eigen terbesar ketiga vektor 0,199, prioritas keempat sektor adalah sektor pertanian, peternakan dan perikanan dengan nilai eigen vektor dari 0,192 dan prioritas terakhir adalah sektor pariwisata dengan nilai eigen vektor hanya $0,169$.
\end{abstract}

Kata Kunci: AHP; SWOT; RUPM; UMKMK; Kebijakan Investasi

Diterima: 05 Nopember 2013; Direvisi: 30 Desember 2013; Disetujui: 14 Januari 2014 


\section{PENDAHULUAN}

Negara Indonesia merupakan Negara Kesatuan yang berbentuk Republik dan merupakan Negara Hukum. Negara Kesatuan Republik Indonesia menganut asas desentralisasi. Desentralisasi merupakan asas yang menyatakan penyerahan sejumlah urusan pemerintahan dari pemerintah pusat atau dari pemerintah daerah tingkat yang lebih tinggi kepada pemerintah daerah yang lebih rendah sehingga menjadi rumah tangga daerah itu (C. S. T Kansil, 2008).

Hubungan wewenang antara pemerintah pusat dan diatur dengan undang-undang dengan memperhatikan kekhususan dan keragaman daerah dalam rangka penyelenggaraan pemerintahan daerah sesuai dengan amanat Undang-Undang Dasar Republik Indonesia Tahun 1945, pemerintahan daerah yang mengatur dan mengurus urusan pemerintahan menurut asas otonomi dan tugas pembantuan (HAW. Widjaja, 2007).

Rencana Umum Penanaman Modal (RUPM) merupakan dokumen perencanaan yang bersifat jangka panjang sampai dengan tahun 2025. RUPM berfungsi untuk mensinergikan dan mengoperasionalisasikan seluruh kepentingan sektoral terkait, agar tidak terjadi tumpang tindih dalam penetapan prioritas sektor-sektor yang akan dipromosikan. Perencanaan penanaman modal juga penting untuk mensinergikan sejumlah kebijakan sektoral terkait, seperti bidang perindustrian, pertanian, pertambangan dan energi, perdagangan, dan bidang infrastruktur publik. Dengan perencanaan penanaman modal yang sistematis juga diharapkan premis dasar penanaman modal tidak hanya untuk pertumbuhan ekonomi, tetapi lebih pada mendukung upaya pencapaian target pembangunan.

Atas dasar kondisi dan kepentingan itu maka dirasa tepat untuk segera merumuskan dan merencanakan penanaman modal demi tersedianya dana untuk pembiayaan pembangunan di Kota Tangerang Selatan. Selain itu, UU No. 25 Tahun 2007 Tentang Penanaman Modal telah mengamanatkan upaya untuk menarik penanaman modal. Pasal 4 ayat 1 UU No. 25/2007 menyatakan, Pemerintah menetapkan kebijakan dasar penanaman modal untuk mendorong terciptanya iklim usaha nasional yang kondusif bagi penanaman modal untuk penguatan daya saing perekonomian nasional; dan mempercepat peningkatan penanaman modal. 
Maksud dari penelitian ini adalah untuk memberikan penjelasan atau gambaran lebih mendalam dan komprehensif tentang Rencana Umum Penanaman Modal (RUPM) Kota Tangerang Selatan yang sistematik dan bersifat jangka panjang, untuk dijadikan Pedoman Pelaksanaan yang implementatif berdasarkan Kaedah Perencanaan Investasi. Adapun tujuan dari penelitian ini adalah agar penanaman modal dapat menjadi sumber pembiayaan pembangunan, yang pada akhirnya diharapkan bisa meningkatkan kesejahteraan masyarakat.

\section{METODE}

Penelitian dilaksanakan di Kota Tangerang Selatan pada Bulan Juli sampai dengan Desember 2013. Pengumpulan data dilakukan dengan cara Focus Group Discussion (FGD), wawancara, dan studi pustaka. Dalam penelitian ini digunakan metode Analitycal Hierarchy Process (AHP) dan analisis SWOT. Jenis penelitian ini merupakan penelitian kualitatif. Rencana Umum Penanaman Modal Nasional mengindikasikan tujuh (7) elemen utama arah kebijakan penanaman modal nasional, yang terdiri dari : 1. Perbaikan Iklim Penanaman Modal, 2. Mendorong Persebaran Penanaman Modal, 3. Fokus Pengembangan Pangan, Infrastruktur, dan Energi, 4. Penanaman Modal yang Berwawasan Lingkungan (Green Investment), 5. Pemberdayaan Usaha Mikro, Kecil, Menengah, dan Koperasi (UMKMK), 6. Pemberian Fasilitas, Kemudahan, dan/atau Insentif Penanaman Modal dan 7. Promosi Penanaman Modal. Ketujuh elemen tersebut disusun dalam urutan perioritasnya masing masing sebagai bahan dasar penyusunan roadmap arah kebijakan sampai dengan tahun 2025.

Berdasarkan ketentuan dari ketujuh elemen nasional tersebut dan adanya kepentingan lokal Kota Tangerang Selatan berbasis pengembangan KPJU lokal Kota Tangerang Selatan sebagaimana pada ilustrasi sebelumnya, ketujuh elemen diatas disusun kembali berdasarkan skala perioritas dari masing-masing elemen berdasarkan opini stakeholders Kota Tangerang Selatan.

\section{HASIL DAN PEMBAHASAN}

Secara Geografis Kota Tangerang Selatan merupakan kota perbatasan dengan Ibu Kota Negara Republik Indonesia sekaligus menghubungkan Propinsi Banten dengan Propinsi DKI Jakarta serta menghubungkan dengan Propinsi Jawa Barat. Kota ini sebagai daerah penyanggah Propinsi DKI Jakarta. Menurut data demografis Kota Tangerang Selatan memiliki jumlah penduduk relatif meningkat 
dari tahun ke tahun, berdasarkan data BPS yang dilakukan per sepuluh tahunan, jumlah penduduk Kota Tangerang Selatan tahun 2010 sebanyak 1.303 .569 jiwa dengan jumlah penduduk laki-laki sebesar 658.701 jiwa atau sebesar 50,53\% dan penduduk perempuan sejumlah 644.868 jiwa atau 49,47\%. Penduduk Kota Tangerang Selatan pada tahun 2010 meningkat sebesar 10,75\% dari tahun 2009. Peningkatan pertumbuhan periode 2009-2010 merupakan pertumbuhan tertinggi dari 3 (tiga) periode sebelumnya. (RPJMD, Kota Tangerang Selatan, 2011).

Salah satu potensi Kota Tangerang Selatan adalah letak geografisnya yang strategis. Letak geografis Kota Tangerang Selatan yang berbatasan dengan Propinsi DKI Jakarta pada sebelah Utara dan Timur memberikan peluang pada Kota Tangerang Selatan sebagai salah satu daerah penyangga Propinsi DKI Jakarta, selain itu juga sebagai daerah yang menghubungkan Propinsi Banten dengan Propinsi DKI Jakarta. Selain itu, Kota Tangerang Selatan juga sebagai salah satu daerah yang menghubungkan Propinsi Banten dengan Propinsi Jawa Barat. Dengan posisi sedemikian, Tangerang Selatan memiliki akses yang bagus baik dari Bandar udara karena berbatasan dengan Kabupaten dan Kota Tangerang yang memiliki Bandar Udara Internasional Soekarno Hatta, maupun dari laut, karena berbatasan dengan DKI Jakarta yang memiliki Pelabuhan Tanjung Priok. Demikian juga akses melalui daratan, Kota Tangerang Selatan dilalui oleh Jalan Tol Lingkar Luar Jakarta (Jakarta Outer Ring Road/JORR II Pd. Indah-BSD). Selain infrastruktur jalan tol yang sudah eksis tersebut, juga direncanakan akan dibangun beberapa ruas jalan tol. Salah satunya adalah ruas jalan tol Kunciran - Serpong. Ruas jalan tol ini akan akan menlintasi wilayah yang berada di Kota Tangerang dan Kota Tangerang Selatan. Wilayah yang dilewati oleh ruas tol ini adalah Kunciran, Kunciran Indah, Paku Jaya, Pondok Jagung Timur, Jelupang, Parigi Baru dan Jombang. Ruas tol ini nantinya akan menjadi satu dengan ruas-ruas tol lainnya yang sedang direncanakan yaitu ruas Kunciran - Bandara, Jakarta - Tangerang, Jakarta - Serpong, Serpong - Cinere, dan Cinere - JAGORAWI yang termasuk ke dalam jaringan sistem jaringan Jalan Jabodetabekjur. 


\section{Gambar 1. Sektor potensial di Tangerang Selatan}

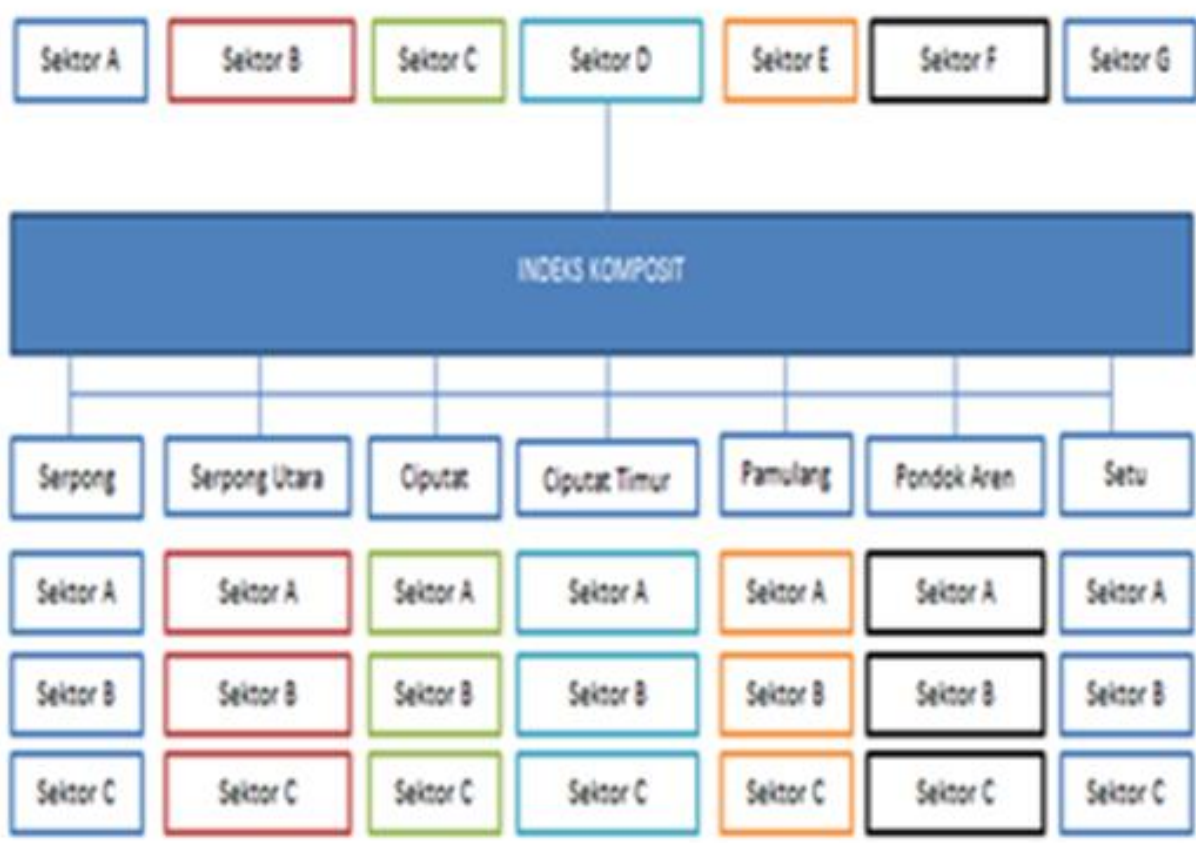

Hasil perhitungan indeks CPI menunjukkan bahwa berdasarkan opini stakeholders potensi KPJU Tangerang Selatan dengan nilai indeks CPI tertinggi adalah sektor perdagangan, industri, hotel dan restaurant dengan nilai indeks sebesar 77,2. Lalu dikuti oleh potensi sektor kesehatan dengan nilai indeks sebesar 74. Kemudian sektor pendidikan mendapatkan nilai indeks terbesar ketiga sebesar 70,5. Lalu diposisi optensial keempat adalah sektor pertanian, peternakan dan perikanan. Sedang potensi terendah adalah sektor pariwisata dengan nilai indeks hanya sebesar 58,7 .

Hasil perhitungan Indeks CPI pada KPJU Kota Tangerang Selatan dapat diajukan sebagai bagian dari dasar pemikiran dalam penentuan dan penyelarasan perioritas arah kebijakan indikatif dari pengembangan penanaman modal di Kota Tangerang Selatan. Stakeholders pemerintahan Kota Tangerang Selatan dapat lebih fokus dalam mengaplikasi tujuaan RUPM dan arahan indikatif kebijakan penanaman modal yang ditetapkan oleh pemerintah pusat dan tentunya dalam hal memberikan peran terbaik kepada pengembangan ekonomi di Propinsi Banten, khususnya dalam hal perbaikan Iklim Penanaman Modal, Pemberian Fasilitas, Kemudahan, dan/atau Insentif Penanaman Modal dan Pemberdayaan Usaha Mikro, Kecil, Menengah, dan Koperasi (UMKMK) yang akan dijelaskan lebih lanjut. 
Tabel 1. Indeks CPI Komoditi/Produk/Jenis Usaha Kota Tangerang Selatan

\begin{tabular}{|c|c|c|c|c|c|c|c|c|c|c|}
\hline \multirow{3}{*}{$\begin{array}{l}\text { Komoditi/Produk / } \\
\text { Jenis Usaha } \\
\text { (KPJU) }\end{array}$} & \multicolumn{9}{|c|}{ Kriteria } & \multirow{3}{*}{$\begin{array}{l}\text { Indeks } \\
\text { Rata } \\
\text { rata }\end{array}$} \\
\hline & \multicolumn{3}{|c|}{ Pasar } & \multicolumn{3}{|c|}{ Bahan Baku } & \multicolumn{3}{|c|}{ Kontribusi } & \\
\hline & jml & NRR & Indeks & Jml & NRR & Indeks & JML & NRR & Indeks & \\
\hline \multicolumn{11}{|l|}{ Sektor Pendidikan } \\
\hline $\begin{array}{l}\text { Universitas } \\
\text { Sekolah Menegah }\end{array}$ & 82,0 & 4,1 & 2,1 & 63,0 & 3,2 & 1,6 & 83,0 & 4,2 & 2,1 & \\
\hline Atas Unggulan & 69,0 & 3,5 & 1,7 & 67,0 & 3,4 & 1,7 & 59,0 & 3,0 & 1,5 & \\
\hline & & & 3,8 & & & 3,3 & & & 3,6 & \\
\hline & & & 75,5 & & & 65,0 & & & 71,0 & 70,5 \\
\hline \multicolumn{11}{|l|}{$\begin{array}{l}\text { Sektor Kesehatan } \\
\text { Rumah Sakit }\end{array}$} \\
\hline $\begin{array}{l}\text { Umum } \\
\text { Rumah Sakit lbu }\end{array}$ & 79,0 & 4,0 & 2,0 & 74,0 & 3,7 & 1,9 & 81,0 & 4,1 & 2,0 & \\
\hline dan Anak & 74,0 & 3,7 & 1,9 & 73,0 & 3,7 & 1,8 & 63,0 & 3,2 & 1,6 & \\
\hline & & & 3,8 & & & 3,7 & & & 3,6 & \\
\hline $\begin{array}{l}\text { Sektor Pertanian, } \\
\text { Peternakan dan } \\
\text { Perikanan }\end{array}$ & & & 76,5 & & & 73,5 & & & 72,0 & 74,0 \\
\hline Sayuran & 61,0 & 3,1 & 0,4 & 60,0 & 3,0 & 0,4 & 83,0 & 4,2 & 0,6 & \\
\hline Buah Buahan & 62,0 & 3,1 & 0,4 & 57,0 & 2,9 & 0,4 & 59,0 & 3,0 & 0,4 & \\
\hline Tanaman Hias & 57,0 & 2,9 & 0,4 & 59,0 & 3,0 & 0,4 & 59,0 & 3,0 & 0,4 & \\
\hline Biofarmaka & 62,0 & 3,1 & 0,4 & 77,0 & 3,9 & 0,5 & $\begin{array}{l}81,0 \\
58\end{array}$ & 4,1 & 0,6 & \\
\hline Ternak Besar & 61,0 & 3,1 & 0,4 & 58,0 & 2,9 & 0,4 & $\begin{array}{c}0 \\
54\end{array}$ & 2,9 & 0,4 & \\
\hline Ternak Kecil & 59,0 & 3,0 & 0,4 & 57,0 & 2,9 & 0,4 & $\begin{array}{c}0 \\
59\end{array}$ & 2,7 & 0,4 & \\
\hline Unggas & 61,0 & 3,1 & 0,4 & 55,0 & 2,8 & 0,4 & 0 & 3,0 & 0,4 & \\
\hline & & & 3,0 & & & 3,0 & & & 3,2 & \\
\hline $\begin{array}{l}\text { Sektor } \\
\text { Perdagangan, } \\
\text { Industri, Hotel dan } \\
\text { Restaurant } \\
\text { Pemukiman }\end{array}$ & & & 59,2 & & & 59,2 & & & 63,4 & 60,6 \\
\hline Horisontal & 96,0 & 4,8 & 0,3 & 98,0 & 4,9 & 0,3 & 97,0 & 4,9 & 0,3 & \\
\hline Pemukiman Vertikal & 65,0 & 3,3 & 0,2 & 83,0 & 4,2 & 0,3 & 78,0 & 3,9 & 0,3 & \\
\hline Hotel & 75,0 & 3,8 & 0,3 & 59,0 & 3,0 & 0,2 & 77,0 & 3,9 & 0,3 & \\
\hline Restaurant & 78,0 & 3,9 & 0,3 & 75,0 & 3,8 & 0,3 & 93,0 & 4,7 & 0,3 & \\
\hline Transportasi & 80,0 & 4,0 & 0,3 & 77,0 & 3,9 & 0,3 & 87,0 & 4,4 & 0,3 & \\
\hline Komunikasi & 68,0 & 3,4 & 0,2 & 75,0 & 3,8 & 0,3 & 70,0 & 3,5 & 0,2 & \\
\hline $\begin{array}{l}\text { Perdagangan } \\
\text { Lembaga }\end{array}$ & 97,0 & 4,9 & 0,3 & 79,0 & 4,0 & 0,3 & 83,0 & 4,2 & 0,3 & \\
\hline Keuangan & 81,0 & 4,1 & 0,3 & 80,0 & 4,0 & 0,3 & 97,0 & 4,9 & 0,3 & \\
\hline Industri Pengolahan & 82,0 & 4,1 & 0,3 & 67,0 & 3,4 & 0,2 & 60,0 & 3,0 & 0,2 & \\
\hline Listrik & 76,0 & 3,8 & 0,3 & 65,0 & 3,3 & 0,2 & 72,0 & 3,6 & 0,3 & \\
\hline Gas & 81,0 & 4,1 & 0,3 & 68,0 & 3,4 & 0,2 & 77,0 & 3,9 & 0,3 & \\
\hline Air Bersih & 74,0 & 3,7 & 0,3 & 60,0 & 3,0 & 0,2 & 63,0 & 3,2 & 0,2 & \\
\hline Bangunan & 78,0 & 3,9 & 0,3 & 80,0 & 4,0 & 0,3 & 94,0 & 4,7 & 0,3 & \\
\hline
\end{tabular}




\begin{tabular}{|c|c|c|c|c|c|c|c|c|c|c|}
\hline \multirow{3}{*}{$\begin{array}{l}\text { Komoditi/Produk / } \\
\text { Jenis Usaha } \\
\text { (KPJU) }\end{array}$} & \multicolumn{9}{|c|}{ Kriteria } & \multirow{3}{*}{$\begin{array}{c}\text { Indeks } \\
\text { Rata } \\
\text { rata }\end{array}$} \\
\hline & \multicolumn{3}{|c|}{ Pasar } & \multicolumn{3}{|c|}{ Bahan Baku } & \multicolumn{3}{|c|}{ Kontribusi } & \\
\hline & jml & NRR & Indeks & $\mathrm{Jml}$ & NRR & Indeks & JML & NRR & Indeks & \\
\hline \multirow[t]{3}{*}{ Art dan furniture } & 80,0 & 4,0 & 0,3 & 59,0 & 3,0 & 0,2 & 78,0 & 3,9 & 0,3 & \\
\hline & & & 3,9 & & & 3,6 & & & 4,0 & \\
\hline & & & 78,9 & & & 72,8 & & & 79,9 & 77,2 \\
\hline \multirow{3}{*}{$\begin{array}{l}\text { Sektor Pariwisata } \\
\text { Wisata Alam dan } \\
\text { Air } \\
\text { Belanja Kuliner dan } \\
\text { hiburan }\end{array}$} & & & & & & & & & & \\
\hline & 39,0 & 2,0 & 0,6 & 43,0 & 2,2 & 0,7 & 61,0 & 3,1 & 1,0 & \\
\hline & 95,0 & 4,8 & 1,6 & 80,0 & 4,0 & 1,3 & 96,0 & 4,8 & 1,6 & \\
\hline \multirow[t]{3}{*}{ Budaya } & 43,0 & 2,2 & 0,7 & 38,0 & 1,9 & 0,6 & 39,0 & 2,0 & 0,6 & \\
\hline & & & 2,9 & & & 2,7 & & & 3,2 & \\
\hline & & & 58,4 & & & 53,1 & & & 64,7 & 58,7 \\
\hline
\end{tabular}

Sumber : data diolah

Rencana Umum Penanaman Modal Nasional mengindikasikan tujuh (7) elemen utama arah kebijakan penanaman modal nasional, yang terdiri dari : 1. Perbaikan Iklim Penanaman Modal; 2. Mendorong Persebaran Penanaman Modal; 3. Fokus Pengembangan Pangan, Infrastruktur, dan Energi; 4. Penanaman Modal yang Berwawasan Lingkungan (Green Investment); 5. Pemberdayaan Usaha Mikro, Kecil, Menengah, dan Koperasi (UMKMK); 6. Pemberian Fasilitas, Kemudahan, dan/atau Insentif Penanaman Modal; dan 7. Promosi Penanaman Modal. Ketujuh elemen tersebut disusun dalam urutan perioritasnya masing masing sebagai bahan dasar penyusunan roadmap arah kebijakan sampai dengan tahun 2025.

Berdasarkan ketentuan dari ketujuh elemen nasional diatas dan adanya kepentingan lokal Kota Tangerang Selatan berbasis pengembangan KPJU lokal Kota Tangerang Selatan sebagaimana pada ilustrasi sebelumnya, ketujuh elemen di atas disusun kembali berdasarkan skala prioritas dari masing-masing elemen berdasarkan opini stakeholders Kota Tangerang Selatan. Dengan bantuan AHP, opini stakeholders menunjukkan arah kebijakan sebagaimana Tabel 2.

Bersumber dari model AHP yang sama, memperhatikan perioritas elemen dari arahan kebijakan indikatif nasional yang disesuaikan dengan kepentingan Kota Tangerang Selatan, sektor-sektor yang menjadi prioritas sebagai sektor tujuan penanaman modal (ditentukan berdasarkan opini stakeholders) menunjukkan bahwa sektor perdagangan, industri, hotel dan resturan merupakan sektor yang dipertimbangkan pada prioritas pertama dengan nilai eigen vector sebesar 0,232. Lalu dikuti oleh sebagai prioritas sektor kesehatan dengan nilai eigen vector 
sebesar 0,202. Kemudian sektor pendidikan mendapatkan nilai eigen vector terbesar ketiga sebesar 0,199. Lalu di posisi prioritas keempat adalah sektor pertanian, peternakan dan perikanan dengan nilai eigen vector sebesar 0,192 dan perioritas terakhir adalah sektor pariwisata dengan nilai eigen vector hanya sebesar 0,169 .

Tabel 2. Arah Kebijakan

\begin{tabular}{|c|c|c|c|}
\hline No & Elemen Arah Kebijakan & Sub Elemen & $\begin{array}{c}\text { Eigen } \\
\text { Vector } \\
\text { AHP }\end{array}$ \\
\hline \multirow[t]{6}{*}{1} & $\begin{array}{ll}\text { Perbaikan } \quad \text { Iklim } \\
\end{array}$ & & 0.298 \\
\hline & Penanaman Modal & $\begin{array}{l}\text { Penguatan Kelembagaan Penanaman } \\
\text { Modal }\end{array}$ & 0.125 \\
\hline & & $\begin{array}{l}\text { Pengaturan Bidang Usaha Tertutup dan } \\
\text { Terbuka }\end{array}$ & 0.022 \\
\hline & & Pengaturan Persaingan Usaha & 0.044 \\
\hline & & Pengaturan Hubungan Industrial & 0.028 \\
\hline & & $\begin{array}{l}\text { Pengaturan Sistem Perpajakan dan } \\
\text { Kepabeanan }\end{array}$ & 0.08 \\
\hline \multirow[t]{5}{*}{2} & Persebaran & & 0.046 \\
\hline & Penanaman Modal & $\begin{array}{l}\text { Pengembangan pusat ekonomi dan klaster } \\
\text { industri }\end{array}$ & 0.004 \\
\hline & & $\begin{array}{l}\text { Pengembangan pusat-pusat pertumbuhan } \\
\text { strategis }\end{array}$ & 0.015 \\
\hline & & Pengembangan sumber energi & 0.007 \\
\hline & & $\begin{array}{l}\text { Pemberian fasilitas, kemudahan, dan } \\
\text { insentif }\end{array}$ & 0.02 \\
\hline \multirow[t]{8}{*}{3} & Pengembangan & & 0.066 \\
\hline & Pangan, Infrastruktur, dan & Bidang pangan sebagai isu strategis & 0.01 \\
\hline & Energi & Bidang infrastruktur sebagai isu strategis & 0.015 \\
\hline & & $\begin{array}{l}\text { Menetapkan bidang energi sebagai isu } \\
\text { strategis }\end{array}$ & 0.004 \\
\hline & & Teknologi ramah lingkungan & 0.007 \\
\hline & & i hijau & 0.009 \\
\hline & & cemar & 0.007 \\
\hline & & Tata ruang Daya dukung lingkungan & 0.016 \\
\hline \multirow[t]{3}{*}{4} & Pemberdayaan & & 0.13 \\
\hline & Mikro, Kecil, Menengah, & Strategi Naik Kelas & 0.098 \\
\hline & dan Koperasi (UMKMK) & Strategi Aliansi Strategis & 0.033 \\
\hline \multirow[t]{4}{*}{5} & Pemberian & & 0.277 \\
\hline & Kemudahan, & Pemberian fasilitas penanaman modal & 0.158 \\
\hline & Penanaman & Pemberian kemudahan penanaman modal & 0.079 \\
\hline & Modal & Pemberian insentif penanaman modal & 0.04 \\
\hline \multirow[t]{4}{*}{6} & Penanaman & & 0.182 \\
\hline & Modal & $\begin{array}{l}\text { Image building sebagai daerah tujuan } \\
\text { investasi }\end{array}$ & 0.026 \\
\hline & & $\begin{array}{l}\text { Strategi promosi yang lebih fokus dan } \\
\text { inovatif; }\end{array}$ & 0.052 \\
\hline & & Peningkatan peran koordinasi promosi & 0.104 \\
\hline
\end{tabular}

Sumber : data diolah

Peta jalan atau road map adalah sebuah arahan (direction) bagi usaha pengembangan yang bersifat strategis, berskala besar, dan berdurasi panjang. 
Esensi sebuah peta jalan adalah adanya jalur-jalur (paths) pengembangan yang bila diikuti akan membawa pelakunya mencapai tujuan pengembangan tersebut. Jalur-jalur ini disusun sedemikian rupa dengan memperhatikan berbagai faktor yang melekat pada konteks, situasi, dan lingkungan pengembangan, sehingga dapat mengantarkan pada pencapaian tujuan dengan tingkat efektivitas dan efisiensi yang tinggi. Efektivitas dan efisiensi dicapai melalui proses pengembangan yang terukur dan sistematis. Ada tiga prinsip dasar yang digunakan dalam menyusun langkah dan tahapan pengembangan:1. Perencanaan yang realistis, 2. Implementasi yang terukur, 3. Kontinuitas antar kegiatan yang terjaga.

Tabel 3. Eagen Vector AHP

\begin{tabular}{llc}
\hline No & \multicolumn{1}{c}{ Sektor } & Eigen Vector AHP \\
\hline 1 & Sektor Perdagangan, industri, hotel dan resturan & $\mathbf{0 . 2 3 2}$ \\
2 & Sektor Kesehatan & 0,202 \\
3 & Sektor Pendidikan & $\mathbf{0 , 1 9 9}$ \\
4 & Sektor Pertanian, peternakan dan perikanan & 0,192 \\
5 & Sektor Pariwisata & 0,169 \\
\hline
\end{tabular}

Sumber : Data diolah

Prinsip kedua, implementasi yang terukur, digunakan untuk keperluan pemantauan (monitoring) dan evaluasi. Dalam pelaksanaan pengembangan, kemajuan yang diperoleh harus dapat diukur dan dibandingkan. Kepentingan ini terkait juga dengan prinsip pertama di atas, karena untuk bisa menjalankan tahapan berikutnya, harus diketahui dahulu kemajuan yang dicapai dalam tahapan sebelumnya. Keterukuran dicapai melalui identifikasi sasaran-sasaran dan indikator pencapaiannya. Indikator-indikator ini bersifat kuantitatif dan digunakan sebagai acuan (referensi) dalam pengukuran ketercapaian sasaran. Dengan membandingkan antara kondisi baseline, kondisi yang harus dicapai (sasaran yang ditetapkan), dan capaian yang sebenarnya, dapat diketahui seberapa jauh tingkat kemajuan pengembangan. Pengetahuan tentang kemajuan ini sangat berguna untuk menentukan langkahlangkah selanjutnya. Jika misalnya ada penyimpangan dari rencana yang telah ditetapkan, hasil pemantauan (monitoring) dapat menjadi dasar bagi usaha-usaha perbaikan dan akselerasi.

Prinsip ketiga, kontinuitas antar kegiatan, berfungsi menjalin satu kegiatan dengan kegiatan lain dalam membangun satu rangkaian program yang utuh. Kontinuitas kegiatan dimulai sejak tahap perencanaan. Penyusunan kegiatan dilakukan dengan memperhatikan urutan dan persyaratan (prerequisite) dari tiap kegiatan. 
Ada kegiatan yang baru dapat dimulai setelah kegiatan prerequisite-nya diselesaikan. Kontinuitas antar kegiatan harus dijaga pada saat implementasi kegiatan-kegiatan pengembangan, terutama dari aspek ketersediaan sumber daya (SDM dan anggaran). Kendala yang sering muncul adalah komitmen untuk mengalokasikan dana dan sumber daya lainnya dalam rencana anggaran tahunan. Roadmap penanaman modal Kota tangerang selatan adalah sebagaimana berikut:

Fase I: Pengembangan Penanaman Modal yang Relatif Mudah dan Cepat Menghasilkan (Quick Wins and Low Hanging Fruits)

Pada fase ini arahan indikatif yang menjadi fokus adalah kebijakan terkait dengan penguatan kelembagaan, pemberian fasilitas, kemudahan dan atau insentif dalam hal penanaman modal, promosi dan Pemberdayaan Usaha Mikro, Kecil, Menengah, dan Koperasi (UMKMK). Sedangkan dalam konteks pencapaian visi dan misi, pada tahap ini pemerintah Kota Tangerang Selatan fokus kepada faktor-faktor yang terkait dengan penciptaan daya tarik iklim investasi, dengan begitu beberapa kerja yang dapat dikembangkan adalah :

a) Membuka hambatan (debottlenecking) seperti halnya pelayanan publik yang belum optimal, penyusunan dan penyempurnaan peraturan perundang undangan penanaman modal, Peningkatan pelayanan penanaman modal dan penyederhanaan prosedur, melakukan berbagai terobosan kebijakan terkait dengan penanaman modal yang mendesak untuk diperbaiki atau diselesaikan jaringan dan kualitas jalan kota dan penataan lingkungan perkotaan dan memfasilitasi penyelesaian persiapan proyek-proyek besar dan strategis agar dapat segera diaktualisasikan implementasinya.

b) Menggalang kerjasama dengan Pemerintah pusat dalam rangka peningkatan nilai tambah, daya saing penanaman modal yang bernilai tambah tinggi dan pemerataan pembangunan. Khusunya yang terkait dengan penataan dan mengintensifkan strategi promosi penanaman modal pada sektor tersier Kota Tangerang Selatan secara terintegrasi kepada pemerintah pusat dan bahkan ke negara-negara potensial. Seperti halnya meningkatkan peranan BKPMD dalam upaya peningkatan kualitas aparatur dan pelayanan pada dunia usaha dengan berkoordinasi dengan Badan Pendidikan dan Pelatihan Daerah. Memfasilitasi dan mengkoordinasi antara kecamatan dalam penyediaan informasi potensi investasi pada masing-masing daerah. 
c) Mengidentifikasi proyek-proyek penanaman modal di daerah yang siap ditawarkan dan dipromosikan sesuai dengan daya dukung lingkungan hidup dan karakteristik daerah dimaksud, seperti halnya Pembangunan pemukinan vertikal, Kawasan jasa dan perdagangan terpadu.

d) Peningkatan kualitas sumber daya manusia yang dibutuhkan. Pengembangan infrastruktur perlu memasukkan bidang infrastruktur lunak (soft infrastructure), terutama pada bidang pendidikan (tenaga pendidik) dan kesehatan (tenaga medis). Dengan terus mengupayakan jalur investasi pada sektor pendidikan dan kesehatan, Kota Tangerang Selatan dapat mengupayakn dirinya untuk menjadi akses bagi masayarakat seluruh Propinsi Banten untuk mencapai dan menjangkau pendidikan dan kesehatan bertaraf nasional maupun internasional. Mengaplikasikan prinsip link and match dalam pengembangan institusi pendidikan yang lulusannya dipersiapkan memasuki pasar tenaga kerja dengan tidak melupakan nilai-nilai keagamaan, sosial dan budaya. Untuk itu, institusi pendidikan yang harus segera dikembangkan adalah institusi pendidikan setingkat diploma atau politeknik. Pemerintah melakukan kerjasama dengan pihak swasta dalam pengembangan lembaga pendidikan dan pelatihan guna menyiapkan tenaga kerja yang siap pakai.

Fase II: Percepatan Pembangunan Infrastruktur dan Energi

Pada fase ini arahan indikatif yang menjadi fokus adalah kebijakan terkait dengan fokus pengembangan pangan, infrastruktur, dan energi. Sedang dalam konteks pencapaian visi dan misi, pada tahap ini pemerintah Kota Tangerang Selatan fokus kepada faktor-faktor strategis yang terkait dengan transformasi Know How, entrepreneurship, profesionalisme dan aksesibility modal dan pelayanan. Dengan begitu beberapa kerja yang dapat dikembangkan adalah :

a) Prioritas terhadap peningkatan kegiatan penanaman modal perlu difokuskan pada percepatan pembangunan infrastruktur dan energi melalui skema Kerjasama Pemerintah-Swasta (KPS), peningkatan fasilitasi terwujudnya kerjasama investasi PPMA dan PMDN dengan UMKM diantaranya pembangunan, pembangunan instalasi air bersih, terminal terpadu bis antar kota, propinsi, gedung parikir dan kereta api, monorail dan pengolahan sampah ramah lingkungan. Melakukan penyempurnaan/revisi atas peraturan perundang-undangan yang berkaitan dengan penanaman modal dalam rangka percepatan pembangunan infrastruktur dan energi. 
b) Pemberian fasilitas, kemudahan, dan/atau insentif penanaman modal untuk kegiatan-kegiatan penanaman modal yang mendukung pengimplementasian kebijakan energi nasional oleh seluruh pemangku kepentingan terkait.

c) Penyiapan kebijakan pendukung termasuk peraturan perundang-undangan dalam rangka pengembangan energi di masa datang.

Fase III: Pengembangan Industri Skala Besar

Pada fase ini arahan indikatif yang menjadi fokus adalah kebijakan terkait dengan mendorong persebaran penanaman modal. Sedang dalam konteks pencapaian visi dan misi, pada tahap ini pemerintah Kota Tangerang Selatan fokus kepada perwujudan daya saing iklim investasi, dimana faktor-faktor strategis yang terkait dengan produktifitas dan efesiensi menjadi isu utama dalam penciptaan program kerja.

a) Pemetaan lokasi pengembangan klaster industri termasuk penyediaan infrastruktur keras dan lunak yang mencukupi termasuk pemberian fasilitas, kemudahan, dan/atau insentif penanaman modal daerah. Klaster industri ini diharapakan akan menjadi penyangga ekonomis bagi kawasan strategis ekonomi Kota Tangerang Selatan, yaitu Bumi Serpong Damai, Alam Sutera dan Bintaro Jaya.

b) Pengembangan peta potensi sumber daya dan value chain distribusi pada kawasan strategis sosial budaya di kecamatan Ciputat, kawasan strategis fungsi dan daya dukung lingkungan di Situ Gintung dan kawasan pendayagunaan sumber daya alam dan teknologi tinggi pada Kecamatan Setu (Puspitek) untuk mendukung pengembangan klaster-klaster industri dan pengembangan ekonomi.

c) Koordinasi penyusunan program dan sasaran kedinasan/ lembaga teknis dan instansi penanaman modal daerah dalam mendorong industrialisasi skala besar.

d) Pengembangan sumber daya manusia yang handal dan memiliki keterampilan (talent worker).

Fase IV: Pengembangan Ekonomi Daerah Berbasis Pengetahuan (KnowledgeBased Economy)

Pada fase ini arahan indikatif yang menjadi fokus adalah kebijakan terkait dengan seluruh kebijakan khususnya penanaman modal yang berwawasan lingkungan 
(green investment). Sedang dalam konteks pencapaian visi dan misi, pada tahap ini pemerintah Kota Tangerang Selatan fokus kepada upaya mempertahankan daya saing iklim investasi, dimana faktor-faktor strategis yang terkait inovasi produk berkelanjutan dan jaringan pasar menjadi isu utama dalam penciptaan program kerja.

a) Mempersiapkan kebijakan dalam rangka mendorong kegiatan penanaman modal yang inovatif, mendorong pengembangan penelitian dan pengembangan (research and development), menghasilkan produk berteknologi tinggi, dan efisiensi dalam penggunaan energi.

b) Menjadi negara industri yang ramah lingkungan.

c) Mendorong pembangunan kawasan ekonomi berbasis teknologi tinggi (Industrial-Technology Park/ technopark). Industrial-technology park merupakan tempat bersinerginya Perguruan Tinggi, R\&D Institution dan Industri. Di tempat ini diharapkan akan muncul techno-preneurship baru. Pada tahap ini, PDB perkapita Indonesia diperkirakan sudah tinggi sehingga untuk meningkatkan pendapatan tenaga kerja yang lebih tinggi lagi hanya dapat diperoleh dari sektor high-skilled labor industries.

d) Kota tangerang selatan sudah mampu mencapai efesiensi semua pillar daya tarik, tahan dan saing yang kemudian membentuk efficiency driven economies yang dicapai melalui pilar pendidikan tinggi dan pelatihan (higher education and training), pilar efisiensi pasar barang (goods market efficiency), pilar efisiensi pasar tenaga kerja (labour market efficiency), pilar efisiensi pasar keuangan (financial market efficiency), pilar kesiapan teknologi (technological readiness) dan pilar ukuran pasar (market size).

Dalam kerangka kemampuan untuk "memotret" kondisi pada periode kekinian, opini stakeholders yang hadir diukur untuk melihat kondisi kekinian terkait dengan program-program berjalan di pemerintahan Kota Tangerang Selatan dalam hal penyehatan iklim investasi berdaya tarik, tahan dan saing. Hal ini menjadi penting dalam kerangka menyusun target-target yang dapat tercapai di atas, dan merencanakan kegiatan-kegiatan yang efektif dalam mencapai target-target tersebut. Rating strategi pengembangan daya tarik, tahan dan saing iklim investasi berbasis KPJU unggulan didapat dan diolah dari hasil kesepakatan para narasumber ahli yang hadir FGD. Rating diasumsikan sebagai angka-angka skor yang disepakati berdasarkan hasil kesepakatan para narasumber. Rating diharapkan sesuai dengan pengalaman responden terkait dengan pengembangan 
daya tarik, tahan dan saing iklim investasi yang mengacu kepada KPJU unggulan.

Ketentuan skor adalah sebagaimana berikut:

Tabel 4. Keterangan Skor dan Nilai

\begin{tabular}{cll}
\hline Skor & \multicolumn{1}{c}{ Nilai } & \multicolumn{1}{c}{ Keterangan } \\
\hline 1 & Tidak mendukung & Tidak perlu \\
2 & Kurang mendukung & Perlu tapi sangat sulit direalisasikan \\
3 & Mendukung & Perlu tapi agak sulit direalisasikan \\
4 & Sangat Mendukung & Perlu dan tidak sulit untuk direalisasikan \\
\hline
\end{tabular}

Sumber. Instrumen Penelitian

Hasil pembahasan rating kesepakatan antara narasumber adalah sebagaimana pada Tabel 5.

Tabel 5. Rating Strategi Daya Tarik, Tahan dan Saing

\begin{tabular}{|c|c|c|}
\hline \multicolumn{2}{|r|}{ DAYA TARIK } & \multirow{2}{*}{$\frac{\text { Rating }}{3.0}$} \\
\hline 1 & $\begin{array}{l}\text { Kota Tangerang Selatan perlu mengembangkan program-program } \\
\text { yang terkait dengan penyehatan investasi }\end{array}$ & \\
\hline 2 & $\begin{array}{l}\text { Kota Tangerang Selatan perlu mengembangkan program-program } \\
\text { yang terkait dengan Pengembangan Iklim ekonomi agar lebih dinamis }\end{array}$ & 3.2 \\
\hline 3 & $\begin{array}{l}\text { Kota Tangerang Selatan perlu mengembangkan program-program } \\
\text { yang terkait dengan Pengembangan SDM KPJU UMKM agar lebih } \\
\text { Kompetitif }\end{array}$ & 3.0 \\
\hline 4 & $\begin{array}{l}\text { Kota Tangerang Selatan masih perlu mengembangkan program- } \\
\text { program yang terkait dengan Citra KPJU UMKM lokal } \\
\text { DAYA TAHAN }\end{array}$ & 3.4 \\
\hline 5 & $\begin{array}{l}\text { Kota Tangerang Selatan perlu mengembangkan program-program } \\
\text { yang terkait dengan Bantuan/pelatihan untuk Transformasi Know How } \\
\text { pengembangan KPJU UMKM Unggulan }\end{array}$ & 2.8 \\
\hline 6 & KPJU UMKM Unggulan masih perlu pengembangan entrepreneurship & 3.2 \\
\hline 7 & $\begin{array}{l}\text { KPJU UMKM Unggulan masih perlu menerima meningkatkan } \\
\text { profesionalisme }\end{array}$ & 2.6 \\
\hline \multirow[t]{2}{*}{8} & $\begin{array}{l}\text { Kota Tangerang Selatan perlu mengembangkan program-program } \\
\text { yang terkait dengan pembukaan aksesibilties modal, infrastruktur dan } \\
\text { pelayanan }\end{array}$ & 3.4 \\
\hline & DAYA SAING & \\
\hline 9 & $\begin{array}{l}\text { KPJU UMKM unggulan masih perlu mengembangkan produktifitas dan } \\
\text { efesiensi }\end{array}$ & 3.2 \\
\hline 10 & $\begin{array}{l}\text { KPJU UMKM unggulan masih perlu menerima pelatihan yang berkaitan } \\
\text { dengan Inovasi produk berkelanjutan }\end{array}$ & 3.6 \\
\hline 11 & KPJU UMKM Unggulan masih perlu mengembangkan Jaringan pasar & 2.4 \\
\hline 12 & $\begin{array}{l}\text { Dalam hal meningkatkan daya saing KPJU UMKM di Kota Tangerang } \\
\text { Selatan, perlu dikembangkan program-program kerjasama antar } \\
\text { kecamatan }\end{array}$ & 3.2 \\
\hline
\end{tabular}

Sumber. Data diolah

Analisis SWOT dikedepankan sebagai metode perencanaan strategis yang digunakan untuk mengevaluasi kekuatan (strengths), kelemahan (weaknesses), peluang (opportunities), dan ancaman (threats) iklim penanaman modal Kota 
Tangerang Selatan. Keempat faktor itulah yang membentuk akronim SWOT (strengths, weaknesses, opportunities, dan threats). Proses ini melibatkan penentuan tujuan yang spesifik dari iklim investasi dan mengidentifikasi faktor internal dan eksternal yang mendukung dan yang tidak dalam mencapai tujuan. Dalam konteks penciptaan iklim investasi Kota Tangerang Selatan, analisis SWOT diterapkan dengan cara menganalisis dan memilah berbagai hal yang mempengaruhi keempat faktornya, khususnya yang terkait dengan stabilitas politik, sosial dan ekonomi, infrastruktur dasar, regulasi dan perpajakan serta birokrasi.

SWOT Penanaman modal Kota Tangerang Selatan diupayakan untuk mampu mengungkap indikator stabilitas yang menciptakan kondisi kondusif untuk usahausaha perbaikan kehidupan rakyat lewat pembangunan ekonomi serta pembangunan di bidang-bidang lain, bahkan menemukan legitimasinya sendiri. Dari paham serta pengalaman empiris Kota tangerang Selatan, lambat laun tumbuh bukan sekadar kebijakan, strategi atau formula, tetapi suatu doktrin. Doktrin perihal stabilitas dinamis yang kondusif untuk pembangunan, stabilitas yang mengundang kepercayaan masyarakat dari dalam dan dari luar untuk menanamkan modalnya di Kota Tangerang Selatan, untuk membantu dan untuk bekerja sama.

Proses pembangunan yang dijalankan tidak hanya dilihat dari segi fisik (physical result) tetapi juga harus mampu melihat sejumlah perubahan (growth with change) yang sifatnya non material. Analisis tidak akan lepas dari upaya mencari pemahaman konteks stabilitas di bidang politik, hukum dan ekonomi. Walaupun pada umumnya melihat perubahan dapat dilihat dari 3 hal yang sangat populer untuk terjadi dalam proses pembangunan, yaitu perubahan struktur ekonomi (dari pertanian kepada industri, dari industri perdagangan ke jasa), perubahan kelembagaan (reformasi birokrasi dan SDM) dan kenaikan perubahan pendapatan per kapita. Berdasarkan hal ini kondisi stabilitas ekonomi dan sosial dapat menjadi indikator kunci dimana dalam konteks ekonomi mengacu kepada GNP per kapita, sedang indikator stabilitas sosial dapat dilihat dari, antara lain Human development index dan physical quality life index. Di lain pihak, menurut teori Alan M. Rugman, ada dua faktor terpenting yang mempengaruhi penanaman modal asing yaitu variabel lingkungan dan variabel internalisasi.

Variabel Lingkungan sering dikenal dengan istilah keunggulan spesifik Negara atau faktor spesifik lokasi. Ada tiga unsur yang membangun variabel lingkungan yaitu:ekonomi, non ekonomi dan modal pemerintah. Variabel ekonomi membangun 
fungsi produksi suatu bangsa secara kolektif, yang secara definitif meliputi semua input faktor yang ada di masyarakat, antara lain tenaga kerja, modal (dana), teknologi, dan tersedianya sumber daya alam dan keterampilan manajemen yang disebut human capital. Adapun variabel non ekonomi yang memotivasi masuknya modal asing adalah keseluruhan kondisi politik, hukum dan sosial budaya yang melekat pada suatu negara. Ada beberapa pengamat yang juga memasukkan faktor pemerintahan yang bersih dan berwibawa pada suatu negara (clean government and good governance) baik tuan rumah (host country) ataupun pemerintah asal penanam modal itu. Selain itu sikap pemerintah yang lebih terbuka dengan segala kebijakannya yang tidak memberatkan para investor asing yang ingin menanamkan modalnya juga menjadi salah satu faktor yang menentukan dalam penanaman modal di suatu lokasi.

Kedua, Variabel Internalisasi atau keunggulan spesifik perusahaan. Ini merupakan variabel perusahaan yang kadang juga disebut sebagai faktor spesifik pemilikan. Jadi dengan adanya teori penanaman modal Pemerintah daerah Kota Tangrang Selatan diharapkan bisa mengetahui bagaimana cara berinvestasi yang menguntungkan kedua belah pihak, Kota Tangerang Selatan berupaya untuk mencari ciri khas yang membedakan dengan Kabupaten dana kota lain serta upaya meningkatkan daya saing iklim investasi, dan bagaimana cara meningkatkan investor asing yang mau menanamkan modalnya di suatu negara.

Berdasarkan ilustrasi sedarhana diatas, dalam kerangka mengulas kekuatan, kelemahan, peluang dan ancaman pada Kota Tangerang Selatan akan berporos kepada kata kuci stabilitas di bidang ekonomi sebagai panglima, politik dan hukum. Sedang ramuan kebijakannya diarahkan untuk menciptakan kepercayaan para investor baik dari dalam negeri maupun luar negeri.

Stabilitas ekonomi; Perkembangan Kota Tangerang Selatan begitu pesatnya selama tiga tahun terakhir. Laju pertumbuhan dalam 3 tahun mencapai rata rata $8,57 \%$, angka ini adalah angka laju pertumbuhan terpesat jika dibandingkan dengan kabupaten/kota lainnya di wilayah Propinsi Banten. Kota Tangerang Selatan sudah memiliki kawasan industri. Luas yang disediakan untuk zona industri adalah seluas 2218,31 hektar dengan 2.386 unit industri yang termanfaatkan. Sedang luas yang disediakan untuk kawasan industri adalah seluas 1284 hektar dengan 1614 unit industri yang termanfaatkan. Untuk kawasan perdagangan terbagi menjadi dua, yaitu kawasan dengan skala kota dan lokal serta kawasan perdagangan jasa. Luas 
yang disediakan untuk kawasan perdagangan skala kota dan lokal adalah seluas 1050 hektar, sedangkan kawasan perdagangan jasa seluas 1224,79 hektar.

Stabilitas politik dan pemerintahan; Kota Tangerang Selatan tidak menjadi daerah yang diasumsikan rawan kejadian politik, meskipun demikian, kehadiran lebih dari 10 ORMAS yang beraktifitas di Kota Tangerang Selatan cukup memberikan rasa kekawatiran tersendiri, khususnya yang terkait dengan pungutan liar dan lainnya yang berkontribusi kepada ekonomi biaya tinggi. Walaupun demikian, kehadiran ormas-ormas tersebut tentunya sedikit memberikan pencerahan kepada pemahaman wawasan politik bagi masyarakat. Oleh sebab itu, kehadirannya harus dilihat sebagai suatu suatu potensi yang diarahkan untuk mendukung kegiatan ekonomi dengan melakukan sejumlah kegiatan pembinaan secara terstruktur dan terprogram dengan baik. Bagaimanapun juga dalam konteks penciptaan klim penanaman modal yang sehat, sektor tersier membutuhkan keamanan usaha yang tinggi di tempat usaha, di masyarakat sekitar tempat usaha, serta dalam lalu lintas pengiriman barang. Sektor primer membutuhkan kemudahan memperoleh hak atas penguasaan tanah, keterbukaan masyarakat terhadap dunia usaha, keamanan usaha, keamanan masyarakat, dampak unjuk rasa yang rendah, etos kerja masyarakat lokal yang tinggi, atau paling tidak keterbukaan masyarakat lokal terhadap tenaga kerja dari luar daerah.

Dalam konteks pemerintahan, Kota Tangerang Selatan belum bisa dikatakan sebagai kota terbaik dalam meberikan pelayanan publik, hal ini dikarenakan umur dari pendirian kota yang masih terbilang muda, sehingga adanya keterbatasan perangkat saran dan perasaran pemerintahan menyebabkan pemberian pelayanan yang kurang optimal. Namun demikian pemerintah Kota Tangerang Selatan terus berusaha untuk terus mengembangkan pelayanannya khususnya terkait dengan penataan regulasi dan birokrasi dalam perspektif keseimbangan waktu dan biaya yang diciptakan. Di tengah kerja penataan, kota Tangerang Selatan juga terus berusaha mengembangkan sistem dalam konteks tata kelola yang baik termasuk korupsi, konsistensi dan kepastian dalam kebijakan pemerintah.

Stabilitas Sosial; Tingkat partisipasi kasar penduduk berpendidikan SD Kota Tangerang Selatan terus mengalami peningkatan yang cukup signifikan dimana yang semula hanya sebesar 97,58 tahun 2008 menjadi 99,25 di tahun 2009, kecenderungan positif juga terlihat di tingkat SLTP dan SLTA untuk angka partisipasi kasar. Untuk tingkat partisipasi murni juga mengalami hal yang sama 
dalam peningkatannnya. Hal ini ditunjang dengan kehadiran sejumlah sekolah unggulan pada tingkat SLTP dan SLTA dan bahkan Universitas berskala nasional dan internasional.

Hal yang menarik menarik ialah pemerintah Kota Tangerang Selatan menetapkan lokasi kawasan pendidikan pada kecamatan Ciputat dan Pamulang. Data jumlah penduduk berdasarkan usia pada tahun 2010 kota Tangerang Selatan masih terlihat angka usia produktif (15-64 tahun) yang masih besar, sekitar 74,95\% jika dibandingkan dengan usia muda dan usia tua. Prosentase besarnya penduduk usia produktif sangat berkaitan dengan potensi tenaga kerja. Di lain pihak, kelengkapan kombinasi sarana pendidikan, kesehatan dan lapangan kerja di Kota Tangerang Selatan juga memberikan peluang bagi usia kerja produktif yang datang dari kota lain, kondisi urban dan persaingan yang bakal terjadi di usia produktif dalam hal pendidikan, kesehatan dan lapangan tenaga kerja tentunya memberikan peluang tersendiri akan terjadinya konflik.

Tabel 6. Hasil Analisis Kekuatan, Kelemahan, Peluang dan Ancaman

\section{KEKUATAN/STRENGTHS}

\begin{tabular}{cl}
\hline No. & \multicolumn{3}{c}{ Aspek } \\
\hline 1 & $\begin{array}{l}\text { Letak lokasi yang strategis ditinjau dari letak yang berdampingan dengan Jakarta } \\
\text { Jaringan Transportasi, telekomunikasi dan infrastruktur dasar lainnya yang } \\
\text { mendukung perkembangan ekonomi }\end{array}$ \\
3 & $\begin{array}{l}\text { Laju pertumbuhan industri tersier dan ketersedian lahannya untuk pengembangan } \\
\text { Potensi pengembangan industri primer dan ketersedian lahannya untuk } \\
\text { pengembangan }\end{array}$ \\
5 & $\begin{array}{l}\text { Pertumbuhan UMKM di Kota Tangerang selatan yang mampu menyerap tenaga kerja } \\
\text { pada sektor tersier } \\
6\end{array}$ \\
$\begin{array}{l}\text { Jumlah penduduk yang besar dalam usia produktif } \\
\text { Memiliki daya dukung dalam konteks pengembangan di bidang pendidikan dan } \\
\text { kesehatan }\end{array}$
\end{tabular}

\section{KELEMAHAN/WEAKNESS}

\begin{tabular}{cl}
\hline No. & \multicolumn{1}{c}{ Aspek } \\
\hline 1 & $\begin{array}{l}\text { Keterbatasan sarana dan prasarana pemerintahan dalam konteks optimalisasi } \\
\text { pelayanan publik pada umumnya dan penciptaan iklim investasi khususnya }\end{array}$ \\
2 & $\begin{array}{l}\text { Kurang kegiatan pembukaan dan pencarian pasar untuk industri lokal yang } \\
\text { memanfaatkan kemajuan teknologi informasi }\end{array}$ \\
3 & $\begin{array}{l}\text { Gunung es kerjasama antar pemerintah Kecamatan, karena kurang kordinasi dan } \\
\text { informasi terkait dengan pengembangan ekonomi lokal }\end{array}$ \\
4 & $\begin{array}{l}\text { Kurang ketersediaan marketing tools daerah dan kegiatan pembukaan dan pencarian } \\
\text { pasar untuk industri lokal yang memanfaatkan kemajuan teknologi informasi } \\
5\end{array}$ \\
6 Lemahnya daya saing SDM penduduk Kota Tangerang Selatan yang terampil dan \\
inovatif khususnya pada sejumlah Kecamatan
\end{tabular}


dan lainnya yang memberikan daya dukung untuk pengembangan investasi Kota Tangerang Selatan

7 Tingkat pengangguran pada usia produktif dan keterbatasan lapangan kerja

\begin{tabular}{|c|c|}
\hline \multicolumn{2}{|r|}{ PELUANG/OPPORTUNITY } \\
\hline No. & Aspek \\
\hline 1 & Peluang pengembangan sektor perdagangan dan jasa \\
\hline 2 & $\begin{array}{l}\text { Optimalisasi lembaga pendidikan sebagai teknologi transfer dan eksistensi } \\
\text { PUSPITEK untuk kepentingan penciptaan iklim investasi }\end{array}$ \\
\hline 3 & $\begin{array}{l}\text { Daerah perbatasan sebagai lokasi pengembangan infrastruktur dan pemukiman yang } \\
\text { terintegrasi }\end{array}$ \\
\hline 4 & Potensi minat investor untuk berinvestasi di Kota Tangerang Selatan \\
\hline 5 & $\begin{array}{l}\text { Adanya sejumlah masyarakat dan institusi pengembang industri yang mengglobalkan } \\
\text { informasi dan ekonomi di wilayah Kota Tangerang Selatan }\end{array}$ \\
\hline 6 & Adanya gerakan reformasi birokrasi dan pengembangan pelayanan publik \\
\hline 7 & $\begin{array}{l}\text { Gerakan Intenasionalisasi lembaga pendidikan dan kesehatan di wilayah kota } \\
\text { Tangerang Selatan }\end{array}$ \\
\hline \multicolumn{2}{|r|}{ ANCAMAN/TREATH } \\
\hline No. & Aspek \\
\hline 1 & $\begin{array}{l}\text { Gangguan keamanan akibat instabilitas politik, sosial dan ekonomi, seperti halnya } \\
\text { budaya ORMAS dalam mengembangkan aktifitas yang berdampak kepada ekonomi } \\
\text { biaya tinggi }\end{array}$ \\
\hline 2 & $\begin{array}{l}\text { Masih adanya masayarakat miskin dan pengangguran usia produktif yang kemudian } \\
\text { mengorganisir eksistensi mereka pada wilayah kerja politik dan ekonomi }\end{array}$ \\
\hline 3 & $\begin{array}{l}\text { Masih rendahnya ketaatan kepada RT RW dalam pemanfaatan ruang dan wilayah } \\
\text { dan pengembangan wilayah pemukiman yang tidak ramah lingkungan }\end{array}$ \\
\hline 4 & Pengendalian migrasi kependudukan \\
\hline 5 & $\begin{array}{l}\text { Persaingan yang tidak kondusif dengan kabupaten/kota lain dalam menarik investor } \\
\text { dari luar }\end{array}$ \\
\hline 6 & Ketidakprofesionalan aparat pemerintahan dalam melayani investor \\
\hline 7 & $\begin{array}{l}\text { Kehadiran tenaga ahli asing dalam mengelola investasi di wilayah Kota Tangerang } \\
\text { Selatan }\end{array}$ \\
\hline
\end{tabular}

Gejolak ekonomi dan politik yang meningkat telah menimbulkan hambatan bagi terciptanya rasa aman dan tenteram yang sangat dibutuhkan masyarakat. Kondisi ini menjadi sangat dilematis apabila dihadapkan dengan keterbatasan dan hambatan yang dihadapi aparat yang bertanggung jawab di bidang pertahanan dan keamanan. Oleh karena itu, dengan mempertimbangkan intensitas ancaman faktual dalam negeri, dikaitkan dengan pola penindakan untuk mengatasi keadaan tersebut. Pengembangan peningkatan peran TNI dan Kepolisian yang profesional menjadi prioritas yang harus diwujudkan di Kota Tangerang Selatan.

Berdasarkan ilustrasi dari stabilitas ekonomi, politik, pemerintahan dan sosial, disusun faktor faktor kekuatan, kelemahan, kesempatan dan ancaman Kota tangerang Selatan dalam konteks penciptaan iklim investasi yang berdaya tarik, tahan dan saing, yaitu sebagaimana Tabel 6 . 
Strategi yang diperoleh berdasarkan analisa SWOT pada Tabel 6 adalah sebagai berikut :

a. Perluasan akses dan peningkatan kualitas pelayanan publik yang mendukung iklim investasi

b. Perluasan akses informasi bagi investor

c. Peningkatan kualitas SDM

d. Peningkatan pemanfaatan dan penguatan sistem Informasi

Alternatif strategi yang dihasilkan Matriks SWOT untuk peningkatan investasi di Kota Tangerang Selatan antara lain :

i. Strategi SO : Mengembangkan strategi promosi yang dapat meningkatkan investasi. Pemanfaatan secara maksimal teknologi informasi dan komunikasi yang dapat dimanfaatkan oleh Pemerintah daerah untuk melakukan promosi kepada para calon investor.

ii. Strategi WO : Membangun sistem pelayanan publik yang efektif dan efisien. Hal ini dapat dilakukan dengan membangun sistem pelayanan perizinan satu atap, memotong jalur birokrasi yang tidak perlu, menertibkan pungutan liar.

iii. Strategi ST : Meningkatkan mutu pendidikan dan pembangunan kualitas SDM serta infrastruktur pendidikan

iv. Strategi WT : Menerapkan sistem manajemen informasi yang terpadu dan peningkatan profesionalisme aparat pelayanan publik

\section{SIMPULAN}

Dari hasil analisis AHP, opini stakeholders menunjukkan arah kebijakan yaitu (1) Perbaikan Iklim Penanaman Modal; (2) Mendorong Persebaran Penanaman Modal; (3) Fokus Pengembangan Pangan, Infrastruktur, dan Energi; (4) Pemberdayaan Usaha Mikro, Kecil, Menengah, dan Koperasi (UMKMK); (5) Pemberian Fasilitas, Kemudahan, dan/atau Insentif Penanaman Modal; dan (6) Promosi Penanaman Modal.

Sektor-sektor yang menjadi prioritas sebagai sektor tujuan penanaman modal menunjukkan bahwa sektor perdagangan, industri, hotel dan restaurant merupakan sektor yang dipertimbangkan pada prioritas pertama dengan nilai eigen vector sebesar 0,232 , prioritas kedua sektor kesehatan dengan nilai eigen vector sebesar 0,202 . Kemudian sektor pendidikan mendapatkan nilai eigen vector terbesar ketiga sebesar 0,199. Selanjutnya di posisi prioritas keempat adalah sektor pertanian, 
peternakan dan perikanan dengan nilai eigen vector sebesar 0,192 dan perioritas terakhir adalah sektor pariwisata dengan nilai eigen vector hanya sebesar 0,169.

Berdasarkan analisis Matriks Internal-Eksternal dan Matriks SWOT maka didapatkan beberapa alternatif strategi yang dipilih yakni mengembangkan strategi promosi yang dapat meningkatkan investasi, membangun sistem pelayanan publik yang efektif dan efisien, meningkatkan mutu pendidikan dan pembangunan kualitas SDM serta infrastruktur pendidikan, dan menerapkan sistim informasi manajemen terpadu dan peningkatan profesionalisme aparat pelayanan publik.

\section{PUSTAKA ACUAN}

Badan Kordinasi Penanaman Modal. 2014. Laporan Penanaman Modal Tahun 2010-2014. Jakarta: BKPM Jakarta.

Badan Pusat Statistik (BPS) Kota Tangerang Selatan. 2011. Tabel Input Output Kota Tangerang Selatan. Banten: BPS Kota Tangerang Selatan.

Badan Perencanaan Pembangunan Daerah. 2012. Rencana Pembangunan Jangka Menengah (RPJMD) Propinsi Banten 2009-2014. Banten: Bappeda Banten.

Blanchard, O. 2003. Macroeconomics. New York: Prentice Hall.

Kansil, C.S.T. 2008. Hukum Keuangan dan Perbendaharaan Negara. Jakarta: Pradnya Paramita.

Lincolin, A. 1999. Teori-Teori Pertumbuhan Ekonomi. Yogyakarta: BPFE Yogyakarta.

Mankiw, G . 2007. Makro Ekonomi. Jakarta: Erlangga.

Nopirin. 2000. Pengantar IImu Ekonomi Makro dan Mikro. Yogyakarta: BPFE Yogyakarta.

Purwosutjipto. 2007. Pengertian Pokok Hukum Dagang Indonesia. Jakarta: Djambatan.

Rugman, A.M. 2004. The Regional Multinationals. MNEs and "Global" Strategic Management. Cambridge: Cambridge University Press.

Sutrisno, dkk. 2008. Hukum Investasi di Indonesia. Jakarta: Rajawali Pers .

Saaty, Vargas. 2001. Models, Methods, Concepts \& Applications of the Analytic Hierarchy Process. India: Kluwer Academic 
Tarigan. 2005. Ekonomi Regional: Teori dan Aplikasi. Jakarta: Bumi Aksara.

Widjaja, HAW. 2008. Otonomi Daerah dan Daerah Ekonomi. Jakarta: Rajawali Press. 